\title{
ELECTRON-MICROSCOPE ILLUSTRATIONS OF DIVISION IN MYCOBACTERIUM LEPRAE
}

\author{
Rosa P. EDWARDS \\ Department of Human Anatomy, University of Oxford
}

Plates XLIX-LII

MYCOBACTERIUM LEPRAE has never convincingly been grown in vitro, so that its morphology must be studied in sections of infected tissues.

The organism grows extremely slowly in its human host and electron microscopy has shown only a few instances of dividing bacteria and those only in a late stage of division (Imaeda, Convit and Lapenta, 1963; Brieger and Allen, 1964; Klingmüller and Orfanos, 1966). Even in tissues from patients with severe untreated lepromatous leprosy, in which there are very numerous bacteria, dividing organisms are seldom seen. This has led some workers (Chatterjee, 1965) to suggest that the dividing form of the organism is a "soft form ", or L-form, and that the stainable acid-fast organisms visible in tissues are some sort of end-product, but do not themselves multiply. However, it has recently been demonstrated that if mice whose immunological capacity has been reduced by thymectomy and total body irradiation are given an inoculation of Myco. leprae, the bacteria multiply to give very high yields (Gaugas, 1967; Rees et al., 1967). In many diagnosed human patients the bacteria have almost reached the stationary phase of growth, but mouse tissues may be sampled during the logarithmic phase, when the number of dividing micro-organisms is correspondingly greater.

The morphology of Myco. leprae from tissues of such mice and the changes found at various stages in the cycle of division have been observed in the electron microscope. These findings are reported here, together with a few observations of division in bacteria from patients with untreated lepromatous leprosy.

\section{MATERIALS AND METHODS}

Tissues were examined from three mice treated as detailed in the table and also from skin and radial nerve biopsies from patients with untreated lepromatous leprosy. The human material was fixed by immersion in either 4 per cent. neutral formaldehyde solution (Richardson, 1960) or in 3 per cent. glutaraldehyde in phosphate buffer $(p \mathrm{H} \mathrm{7.2)}$. The majority of tissues were post-fixed in 1 per cent. phosphate-buffered osmium tetroxide $(p \mathrm{H} 7 \cdot 2)$, embedded in Araldite, sectioned, and stained in uranyl acetate followed by lead citrate. Foot-pad tissues from one mouse, however, were divided into two. One part was processed by the bacterial fixation technique of Kellenberger, Ryter and Séchaud (1958), and the other was fixed in 2.5 per cent. glutaraldehyde in $0.085 \mathrm{M}$ cacodylate buffer (Glauert and Thornley, 1966), washed in 5 per cent. buffered $(p H$ 7.4) sucrose containing calcium chloride, and post-fixed in osmium tetroxide buffered to $p \mathrm{H} 6.1$ as recommended by Kellenberger et al. Both parts were then treated in bulk with uranyl acetate, embedded in Araldite, sectioned and stained with lead citrate. The material was examined either at $60 \mathrm{kV}$ on a Siemens Elmiskop I or at $80 \mathrm{kV}$ on an Elmiskop 101.

Received 21 Oct. 1969; accepted 23 Jan. 1970.

J. MED, MICROBIOL.-VOL. 3 (1970) 
TABLE

Growth of Mycobacterium leprae in thymectomised and total-body irradiated mice examined with the electron microscope

\begin{tabular}{|c|c|c|c|c|c|}
\hline $\begin{array}{c}\text { Source of } \\
\text { mycobacteria }\end{array}$ & $\begin{array}{l}\text { Method of } \\
\text { inoculation } \\
\text { into mouse }\end{array}$ & $\begin{array}{l}\text { Number of } \\
\text { bacteria } \\
\text { inoculated }\end{array}$ & $\begin{array}{c}\text { Survival } \\
\text { time of } \\
\text { mouse (mth) }\end{array}$ & $\begin{array}{c}\text { Tissues } \\
\text { examined with } \\
\text { electron } \\
\text { microscope }\end{array}$ & $\begin{array}{l}\text { Fixation of } \\
\text { tissues for } \\
\text { electron } \\
\text { microscopy }\end{array}$ \\
\hline $\begin{array}{l}\text { Passed from } \\
\text { man through } \\
\text { mouse }\end{array}$ & $\begin{array}{r}\text { Intravenous } \\
\text { (tail vein) }\end{array}$ & $3 \cdot 1 \times 10^{8}$ & 12 & $\begin{array}{l}\text { Peripheral } \\
\text { lymph-nodes }\end{array}$ & $\begin{array}{l}\text { Neutral formal- } \\
\text { dehyde } 4 \text { per } \\
\text { cent. }\end{array}$ \\
\hline $\begin{array}{l}\text { Passed from } \\
\text { man through } \\
\text { mouse }\end{array}$ & $\begin{array}{l}\text { Intravenous } \\
\text { (tail vein) }\end{array}$ & $3 \times 10^{9}$ & 9 & Foot-pad & $\begin{array}{l}\text { Glutaraldehyde } \\
3 \text { per cent. }\end{array}$ \\
\hline Man & $\begin{array}{l}\text { Into hypodermis } \\
\text { in both hind } \\
\text { foot-pads }\end{array}$ & $1 \times 10^{5}$ & 10 & Foot-pad & $\begin{array}{l}\text { Glutaraldehyde } \\
\text { method of } \\
\text { Kellenberger } \\
\text { et al. }\end{array}$ \\
\hline
\end{tabular}

\section{Resting phase}

\section{RESULTS}

Cell wall and surrounding zone. The cell wall is composed of two layers. The inner layer (figs. $1 a$ and 2) is moderately electron-dense and sometimes cannot be distinguished from the outer layer of the plasma membrane. The outer layer is electron-transparent and is made visible in the specimens by a tenuous electron-dense layer on its outer side. The zone between the bacterial cell wall and the host cell cytoplasm presents a wide range of appearances. The wall may be in direct contact with the host cytoplasm (figs. 1a and 2) or separated from it by a membrane (figs. $1 b$ and 3 ). It is more often surrounded by a zone of low electron density, which envelops more than one bacterium and often contains amorphous electron-dense grains or strands. This zone is either in contact with the host-cell cytoplasm (figs. $1 c$ and 4) or the junction is marked by a membrane (figs. $1 d$ and 5) (Imaeda et al., 1963; Imaeda, 1965). Cell walls persist even when the cytoplasm has degenerated and the bacteria are presumably dead (fig. 6).

Plasma membrane. This consists of two electron-dense layers separated by an electron-transparent zone; each is approximately $3 \mathrm{~nm}$ in width. From statistical analysis it is clear that there is no significant difference in the width of the three layers of the plasma membrane. It is normally in contact with both the cell wall and the cytoplasm, but perfect sections of whole bacilli illustrating this are rare, for some separation, presumably due to a minimal degree of plasmolysis, is usually present (fig. 7). In some cases extreme plasmolysis may follow the use of a hypertonic fixative (fig. 8).

Cytoplasmic contents. Mesosomes are not always visible and their position is variable. They are invaginations of triple-layered membranes similar in 
appearance to the plasma membrane, with which, depending upon the plane of section, they are sometimes found to be in continuity (fig. 9). In some bacteria membrane-bounded vesicles were seen lying in the space between the plasma membrane and the cell wall (fig. 8). These may be mesosomes or parts of them that have been extruded during plasmolysis (FitzJames, 1964; Weibull, 1965).

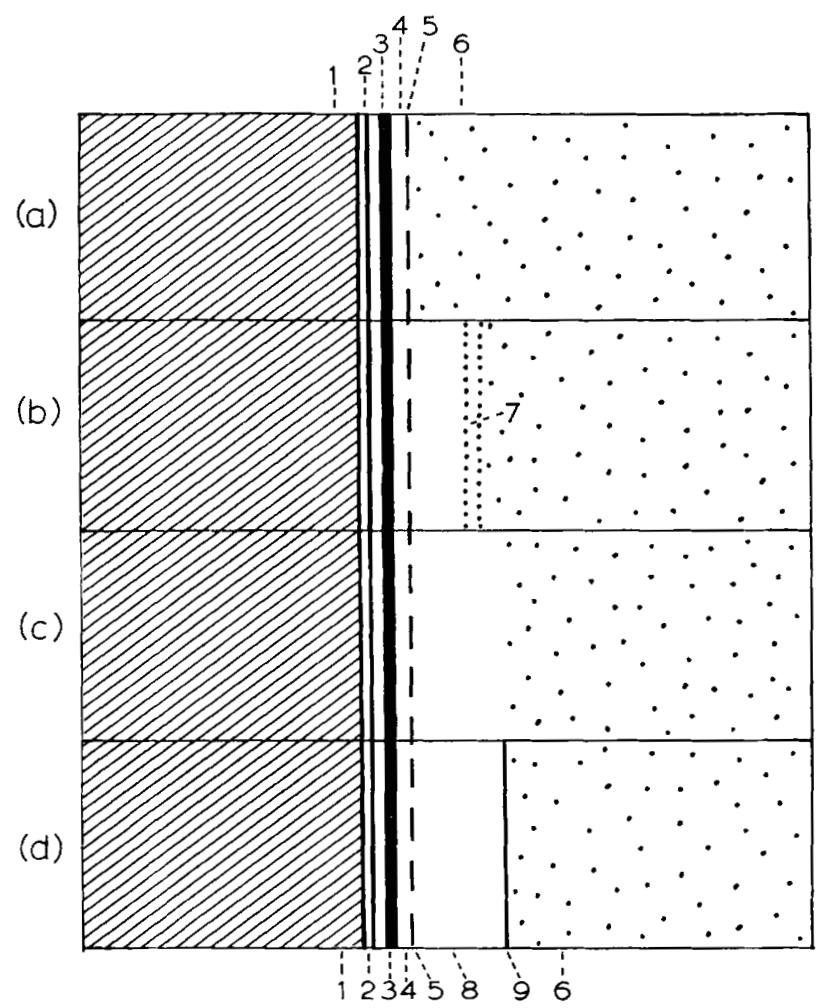

FIG. 1.-Diagrams of four different appearances of the cell wall of Mycobacterium leprae and its surrounding zone shown in figs. 2-5. (a) Appearance of the bacillus lying in direct contact with the host-cell cytoplasm, as in fig. 2. (b) Appearance with a "membrane", as in fig. 3. (c) Appearance with a zone of low electron density surrounding the bacillus and making direct contact with the host-cell cytoplasm, as in fig. 4. $(d)$ Appearance with a zone of low electron density surrounding the bacillus and enclosed by a "junctional membrane", as in fig. 5 . $1=$ Bacterial cytoplasm. 2 = Plasma membrane, consisting of two dense layers on either side of a less dense one. $3=$ Electron-dense layer of cell wall. $4=$ Electron-transparent layer of cell wall. $5=$ Tenuous electron-dense zone outside cell wall. $6=$ Host-cell cytoplasm. $7=$ Membrane, possibly derived from the unit membrane of the cell wall when the bacillus was phagocytosed. $8=$ Zone of low electron density. $9=$ Junctional membrane, formed either at the interface of the host-cell cytoplasmic ground-substance and zone of low electron density or as an extension of a lysosomal membrane.

The nucleoid appears as an electron-transparent zone containing numerous fine electron-dense fibrils which may form aggregations (fig. 7) depending upon fixation (Fuhs, 1965). The cytoplasm also contains granules of variable electron density; some resemble polyphosphate granules seen in other mycobacteria, whilst others (fig. 10) appear to be lipid granules (Imaeda et al., 1963). 


\section{Dividing bacteria}

Division of bacteria in mice. In the earliest stage the plasma membrane forms a slight concavity and two new electron-dense cell-wall layers extend from it to the original cell wall. An electron-transparent layer lies between

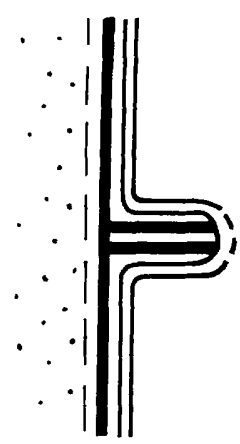

(a)

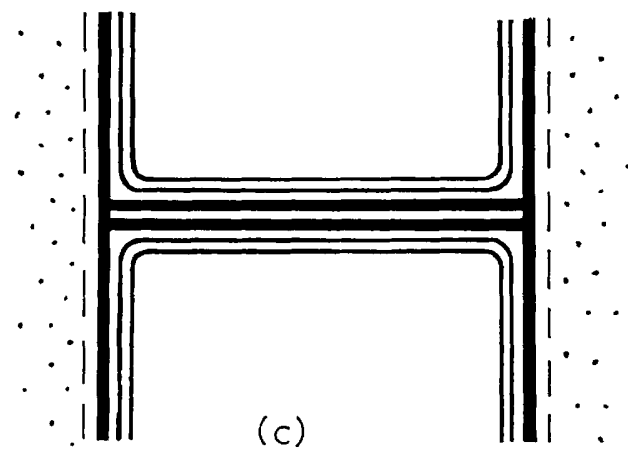

FiG. 11.-Diagrams of different stages of division of a Mycobacterium leprae bacillus as shown in figs. 12-19. (a) The plasma membrane forms a concave ingrowth (figs. 12 and 18), and two new electron-dense cell-wall layers separated by an electron-transparent layer are formed between it and the original cell wall (fig. 12). (b) The annular concavity of the plasma membrane and its contained cell walls grows centripetally until only a narrow cytoplasmic bridge remains (fig. 15). (c) Division is almost complete; the cytoplasmic bridge has been broken, but the original electron-dense cell-wall layer still present joins the lateral cell walls of the daughter bacilli (figs. 16 and 19). (d) The daughter bacilli have rounded ends; the electron-transparent layer between is continuous with that around the cells (fig. 17). 1 = Bacterial cytoplasm. $2=$ Plasma membrane consisting of two denser layers with a less dense layer between. $3=$ Electron-dense layer of the cell wall. $4=$ Electron-transparent layer of the cell wall. $5=$ Tenuous electron-transparent layer outside the cell wall. $6=$ Host-cell cytoplasm.

the dense layers (figs. 1la and 12). Later both plasma membrane and cell walls are seen nearer the centre ("centripetal annular growth") (figs. $11 a$ and 13) forming perforated diaphragms through which there is a cytoplasmic bridge (figs. 11 $a$ and 14). Still later the bridge is very constricted and, because of the plane of the section and depth of field, the new electron-dense cell-wall layers appear to form complete septa (figs. $11 b$ and 15). Even when division is complete and only an electron-transparent zone separates the newly formed 


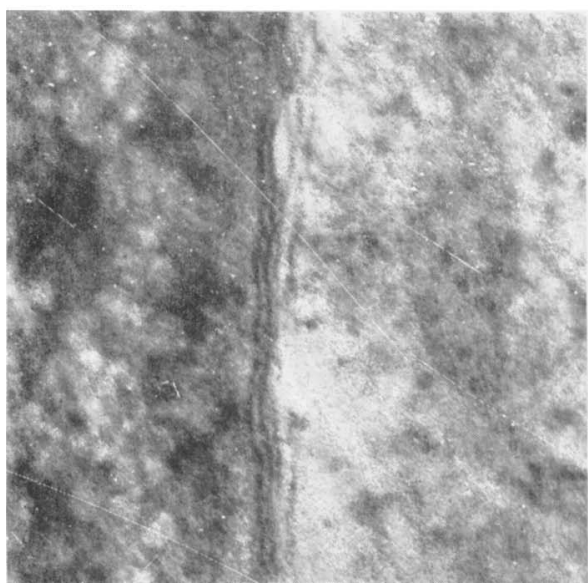

FiG. 2.-Edge of a Mycobacterium leprae bacillus (left) in a mouse lymph-node. See fig. $1 a$ for identification of the structures. $\times 300,000$.

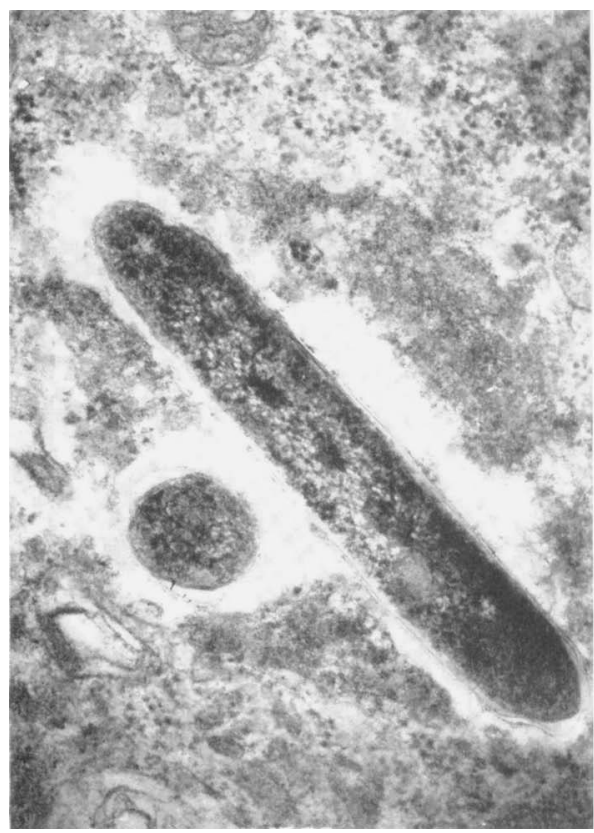

FIG. 4.-Bacillus in a mouse lymph-node. See fig. $1 c . \times 50,000$.

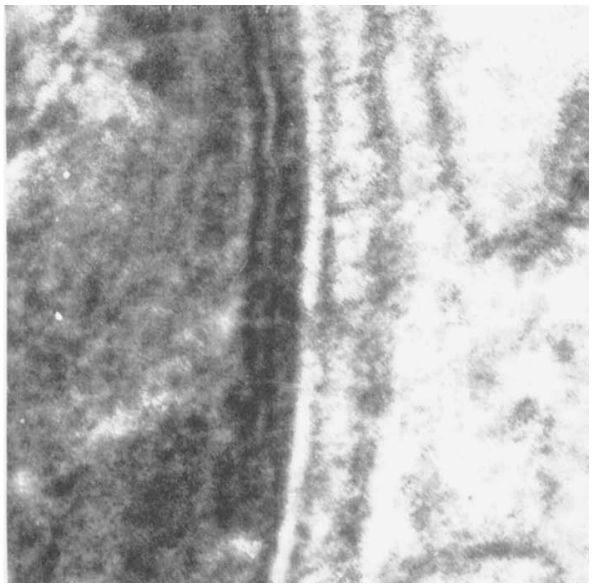

FIG. 3.--Edge of a bacillus (left) in human skin. See fig. $1 b . \times 370,000$.

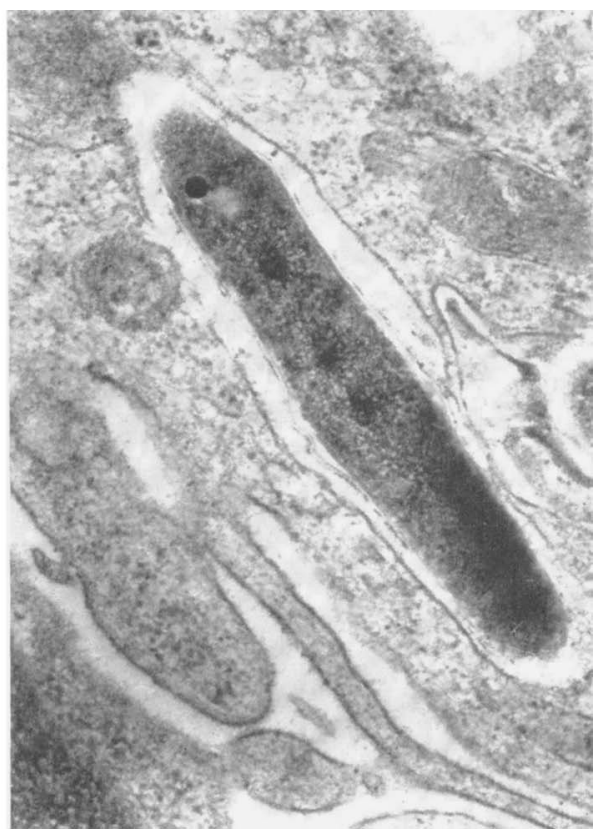

Fig. 5.-Bacillus in a mouse lymph-node. See fig. 1 d. $\times 40,000$.

All specimens fixed with formaldehyde, unless stated otherwise, and photographed with the electron microscope. 


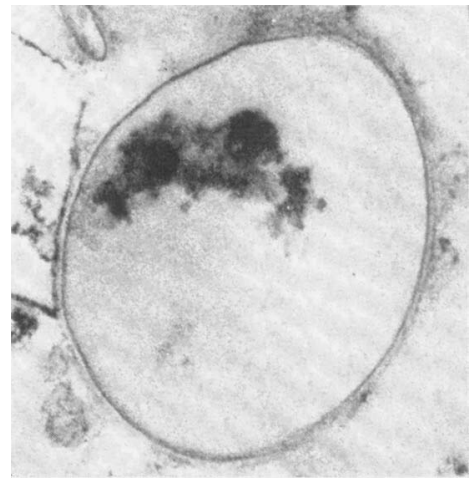

FIG. 6.-Cell wall and residual cytoplasm of a bacillus in human skin. $\times 100,000$.

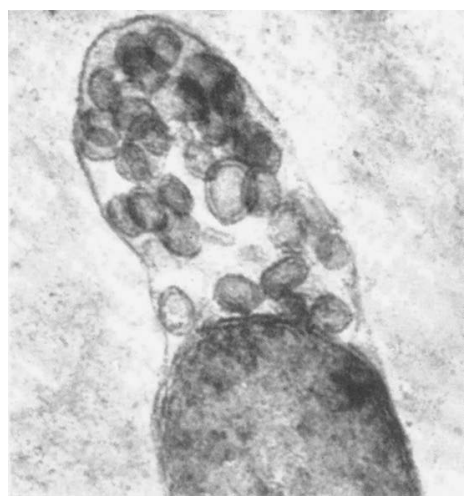

FiG. 8.-Membrane-bounded vesicles in the space between the plasma membrane and the cell wall (plasmolysis) cf a bacillus in a human nerve. Glutaraldehyde fixation. $\times 144,000$.

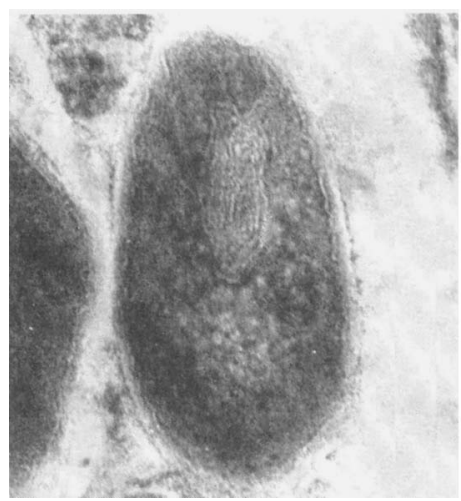

FIG. 9.-Mesosome in continuity with the plasma membrane in a bacillus in a mouse foot-pad. Glutaraldehyde/Kellenberger fixation. $\times 160,000$.

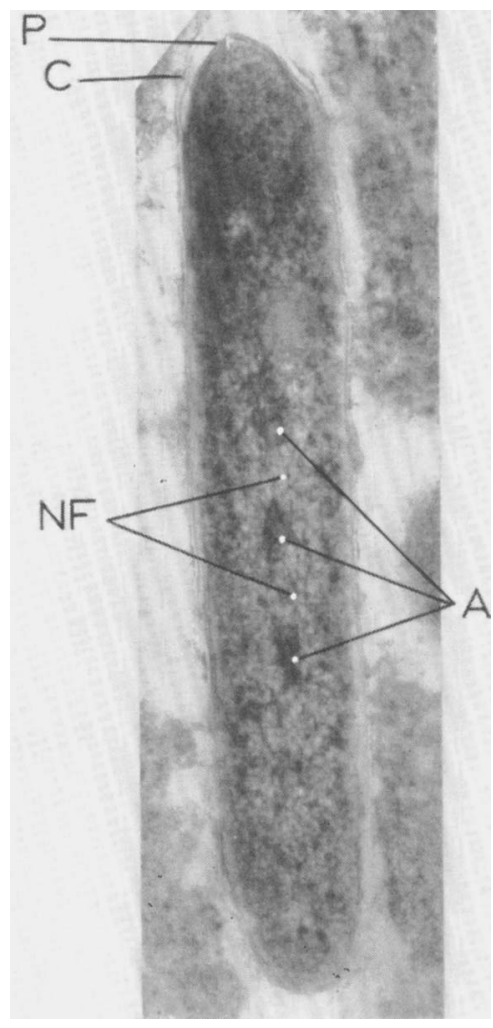

FIG. 7.- Separation of the cell wall from the plasma membrane (plasmolysis) of a bacillus in a mouse lymph-node. NF = Nucleoid fibrils; $\mathrm{A}$ - fibril aggregates; $\mathrm{C}=$ cell wall; $\mathbf{P}=$ plasma membrane. $\times 64,000$.

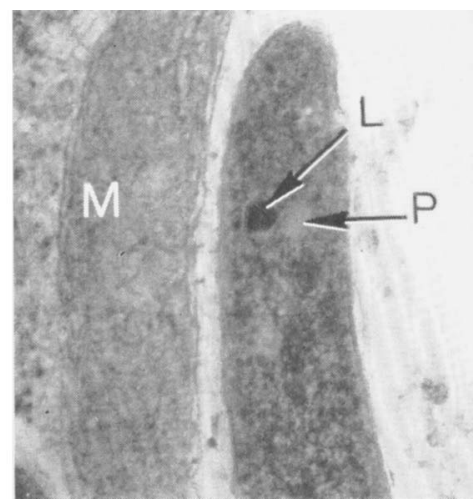

FIG. 10.-Granules in the cytoplasm of a bacillus in a mouse lymph-node. $\mathbf{M}=$ Mitochondrion; $\mathrm{L}=$ polyphosphate granule; $\mathrm{P}=$ lipid granule. $\times 64,000$.

All specimens fixed with formaldehyde, unless stated otherwise, and photographed with the electron microscope. 


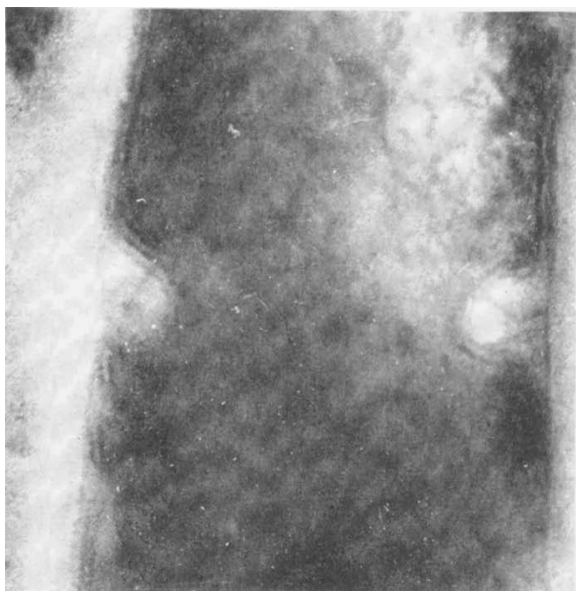

FIG. 12.--Initial stage of division of a bacillus in a mouse lymph-node. $\times 85,000$.

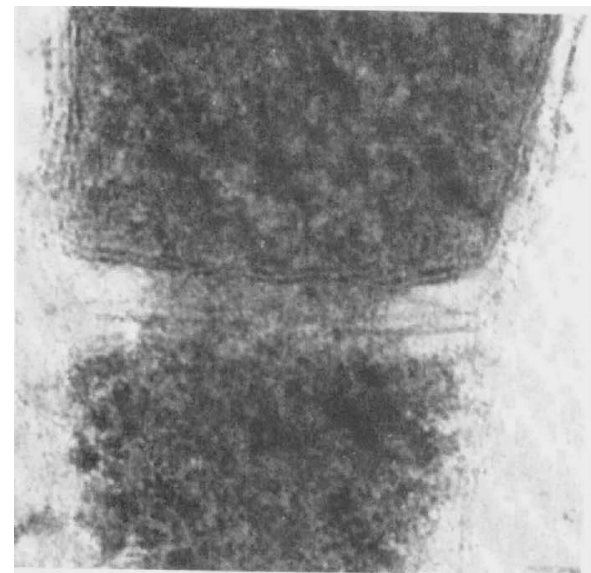

FIG. 14. - Cytoplasmic bridge between daughter cells in a dividing bacillus in a mouse lymph-node. $\times 180,000$.

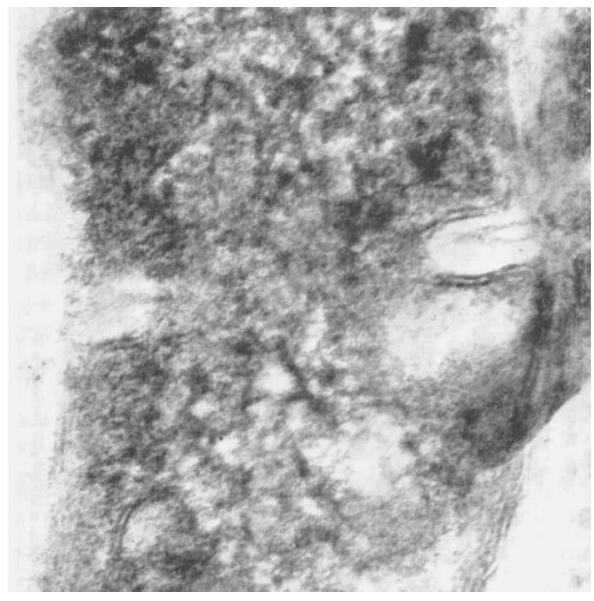

FIG. 13. - Later stage of division of a bacillus in a mouse lymph-node, showing centripetal annular growth. $\times 65,000$.

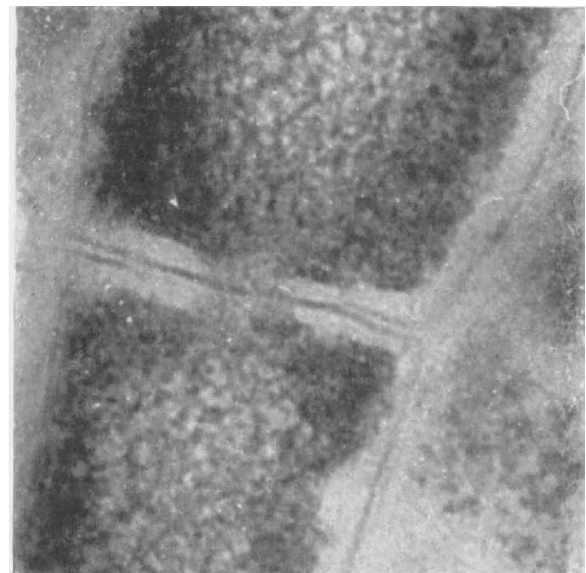

FIG. 15.-Narrower cytoplasmic bridge in a dividing bacillus in a mouse lymph-node. $\times 85,000$.

All specimens fixed with formaldehyde, unless stated otherwise, and photographed with the electron microscope. 


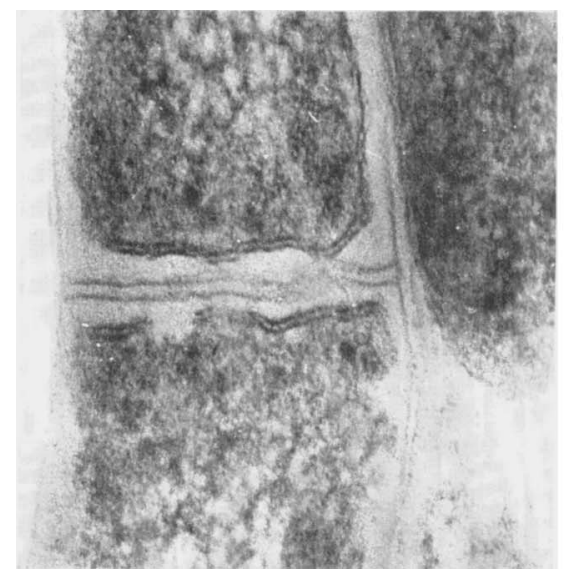

FIG. 16.-Electron-transparent layer separating the daughter cells of a newly divided bacillus in a mouse lymph-node. Note the continuity of the peripheral cell wall. $\times 230,000$.

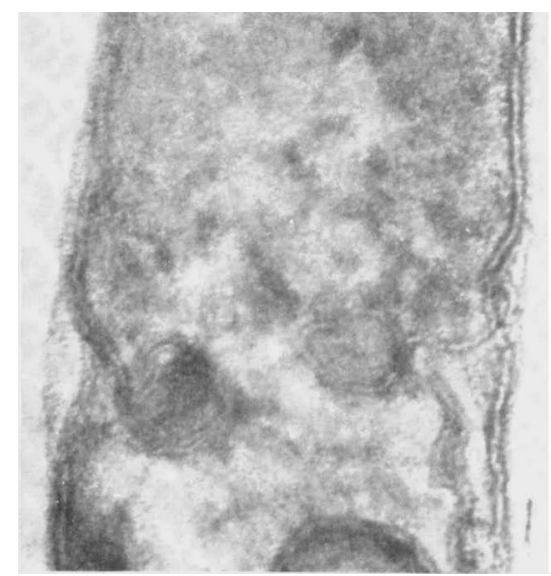

FIG. 18.-Early stage of division of a bacillus in a human nerve. A mesosome lies in contact with the indented plasma membrane. The overlapping images of the plasma membrane are probably due to the surface of both sides of the section being stained. Glutaraldehyde fixation. $\times 240,000$.

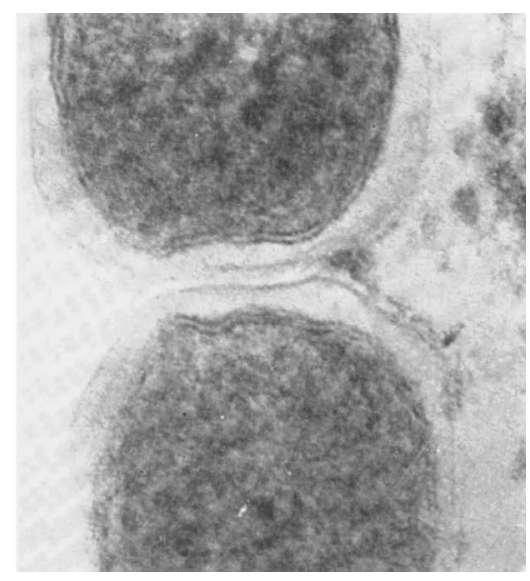

FIG. 17.-Electron-transparent layer surrounding the daughter cell of a newly divided bacillus. $\times 235,000$.

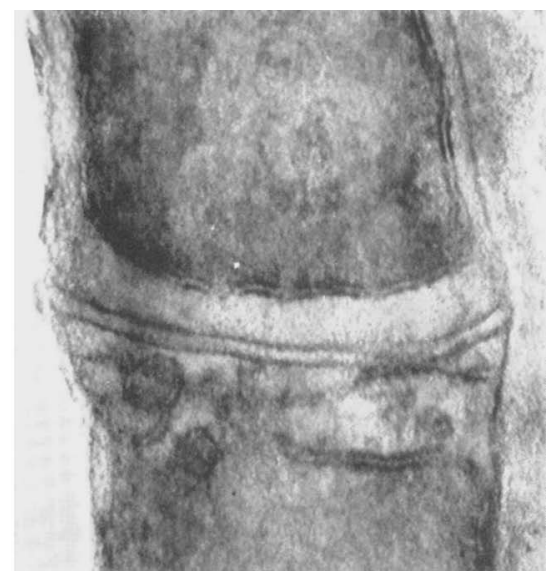

FIG. 19.- Later stage of division of a bacillus in a human nerve. Mesosomal vesicles are extruded in one daughter cell (plasmolysis) (cf. fig. 16). Glutaraldehyde fixation. $\times 225,000$.

All specimens fixed with formaldehyde, unless stated otherwise, and photographed with the electron microscope 
cells, the original electron-dense cell-wall layer is present (figs. 11c and 16). Later this wall disappears and the daughter cells have rounded ends and the electron-transparent layer between them is continuous with the electrontransparent layer of the cells themselves (figs $11 d$ and 17). These last two stages in division are those most commonly found. Complete separation occurs later still. In all the dividing bacteria observed, an electron-transparent region separated the bacterial cytoplasm and plasma membrane from the newly formed cell wall. This is thought to be an artefact caused by plasmolysis.

Division of bacteria in man. Very few dividing bacilli were seen, but the morphological changes found were comparable with those seen in material from mice. For example, in an early stage a mesosome was seen in contact with the indented plasma membrane (fig. 18). In a later stage bacterial division was nearly complete, though the original cell wall was still intact (figs. $11 c$ and 19). In one of the daughter cells the plasma membrane was almost complete, but in the other, owing to plasmolysis, membrane-bounded mesosomal vesicles had been extruded (fig. 19). Daughter cells, united only by the electrontransparent zone of their walls, were seen in a number of sections. A series of drawings illustrating the process of division in Myco. leprae is shown in fig. 11.

\section{Discussion}

Glutaraldehyde fixation followed by post-fixation either with osmium tetroxide buffered at $p \mathrm{H} 7 \cdot 2$ or at $p \mathrm{H} 6 \cdot 1$ according to Kellenberger et al. (1958) gave satisfactory pictures of both bacteria and the cells in which they were situated. The use of Kellenberger's method alone proved unsatisfactory for the study of Mycobacterium leprae in tissues from mice. The use of formaldehyde in $0.75 \mathrm{M}$ sucrose gave rise to plasmolysis and this enabled the plasma membrane to be more clearly observed. It also revealed some of the detailed structure of the vesicles in the space between the plasma membrane and the cell wall, which may be expelled mesosomes (FitzJames, 1964; Weibull, 1965).

The ultrastructure of the cell wall of Myco. leprae was found to be similar to that of other mycobacteria (Imaeda, Kanetsuna and Galindo, 1968), and observations on the plasma membrane of $M y c o$. leprae do not differ from those of other workers who have studied mycobacteria (Imaeda and Ogura, 1963). Comparable variations in the zone surrounding them have also been noted previously (Imaeda, 1965).

During division of Myco. leprae it was observed that both components of the cell wall grow inwards to form a septum. This process is the same as that seen in other dividing mycobacteria (Imaeda and Ogura) and in other Grampositive bacteria (Ellar, Lundgren and Slepecky, 1967; Kakefuda, Holden and Utech, 1967). In human material, bacteria that had reached the stage of completion of the new cell wall, but had not separated, were frequently seen, but other stages were rare. This implies that although bacteria may divide as seldom as once in 2-3 wk, the actual process of formation of the cell wall probably occurs relatively rapidly.

The intracytoplasmic membrane systems now generally referred to as 
mesosomes (FitzJames, 1960) are considered to be formed as invaginations of the plasma membrane. In mycobacteria they are often very elaborate. Their function is still uncertain; it seems likely, however, that they are concerned among other things with the synthesis of the cell wall and nuclear segregation during division (Ellar et al.; Ryter, 1967). Imaeda and Ogura suggested that in $M$ yco. lepraemurium a precursor of the cell wall lies within the invagination and is in contact with the cell wall through a narrow opening. The observations recorded in the present paper are not at variance with the results of other authors (Imaeda and Convit, 1962; Kakefuda et al.), but they do not contribute to the question of whether or not mycobacteria contain more than one mesosome, or whether the mesosomes are invariably associated with cell division, or have some additional function such as electron transport (van Iterson, 1965). It should be noted, however, that in some instances mesosomes were found apparently in close proximity to the site of initiation of division (fig. 18).

\section{SUMMARY}

The sequential changes occurring during bacillary division of Mycobacterium leprae in infected foot-pads of mice and human skin and nerves were studied with the electron microscope and found to be as follows: (1) a slight concavity develops in the plasma membrane, (2) two new electron-dense cell-wall layers are found between the concavity and the original cell wall, and an electrontransparent cell-wall layer appears between them, and gradually separates them, and (3) the annular ingrowth of the plasma membrane and cell wall proceeds until division is complete. There is no essential difference between the behaviour of Myco. leprae and that of other mycobacteria, nor between the behaviour in bacteria obtained from human biopsy specimens and bacteria from infected mice. Although Myco. leprae multiplies slowly the actual process of cell division may be relatively rapid.

I wish to thank Dr R. J. W. Rees, National Institute for Medical Research, Mill Hill, Dr G. Weddell, Department of Human Anatomy, Oxford, and their colleagues for help and encouragement, and Mr Derek Wood for technical assistance.

\section{REFERENCES}

Brieger, E. M., AND Allen, Jennifer 1964. In Leprosy in theory and practice. ed. by R. G. Cochrane and T. F. Davey, Bristol, pp. 36-49.

Chatterjee, B. R. 1965. Int. J. Lepr., 33, Suppl., p. 551.

Ellar, D. J., LundGRen, D. G., AND 1967. J. Bact., 94, 1189.

SLEPECKY, R. S. FITZJAMES, P. C.

1960. J. Biophys. Biochem. Cytol., 8, 507.

FuHS, G. W. 1964. J. Bact., 87, 1483.

GaUGAS, J. M. - . $\quad$. $\quad$. 1967. Br. J. Exp. Path., 48, 417.

Glauert, Audrey M., and Thornley, 1966. J. Roy. Microsc. Soc., 85, 449. MARGARET J.

IMAEDA. T.

1965. Int. J. Lepr., 33, 669.

ImAedA, T., AND Convit, J. $\quad$. $\quad$ 1962. J. Bact., 83, 43 . 
ImaEda, T., Convit, J., AND LAPENTA, P. 1963. Int. J. Lepr., 31, 389.

Imaeda, T., Kanetsuna, F., AND Galindo, 1968. J. Ultrastruct. Res., 25, 46.

B.

IMAEDA, T., AND OGURA, M. . . . 1963. J. Bact., 85, 150.

KaKefudA, T., Holden, J. T., AND UTECH, 1967. Ibid., 93, 472.

N. M.

Kellenberger, E., Ryter, A., AND 1958. J. Biophys. Biochem. Cytol., 4, 671. SÉCHAUD, J.

Klingmüller, G., and Orfanos, C. 1966. Arch. exp. Derm., 224, 373.

Rees, R. J. W., Waters, M. F. R., 1967. Nature, Lond., 215, 599.

Wekkel, A. G. M., AND Palmer,

ELISABETH

Richardson, K. C. $\quad$. $\quad$. $\quad$. $\quad$. 1960. J. Anat., 94, 457.

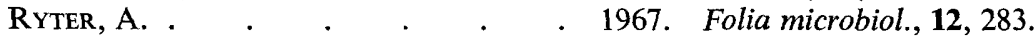

VAN ITERSON, W. $\quad$. $\quad$. . . . 1965. Bact. Rev., 29, 299.

Weibull, C. . . . . . . 1965. J. Bact., 89, 1151. 